\title{
Differences in Students' Reading Comprehension of International Financial Reporting Standards: a South African Case
}

\author{
Stephen A. Coetzee*, Cecile Janse van Rensburg \& Astrid Schmulian \\ Department of Accounting, Faculty of Economic and Management Sciences, University of Pretoria, Pretoria, \\ South Africa
}

*Correspondence author: Stephen A. Coetzee stephen.coetzee@up.ac.za

\begin{abstract}
This study explores differences in students' reading comprehension of International Financial Reporting Standards (IFRS) in a South African financial reporting class with a heterogeneous student cohort. Statistically significant differences were identified for prior academic performance, language of instruction, first language and enrolment in the Thuthuka programme. Where students, in a heterogeneous financial reporting class, require additional interventions to develop their reading comprehension, instructors may need to consider implementing differentiated instruction. Although this study considers South African students, the results may be of interest in other multicultural or multilingual environments, particularly where students also have diverse traits and backgrounds and have to comprehend learning material in a second language.
\end{abstract}

KEY WORDS: Reading comprehension, IFRS, Cloze, students

\section{Introduction}

Reading comprehension, from a teacher's perspective, has been defined as the process through which students apply prior knowledge and experiences when interacting with written text in order to gain meaning and understanding from that text within a particular socio- 
cultural environment (Pardo, 2004) (Figure 1). The purpose of this study is to explore differences, in the reading comprehension of formal authoritative accounting pronouncements, across a heterogeneous cohort of financial reporting students. Specifically, demographic differences in South African financial reporting students' reading comprehension of International Financial Reporting Standards (IFRS) is explored.

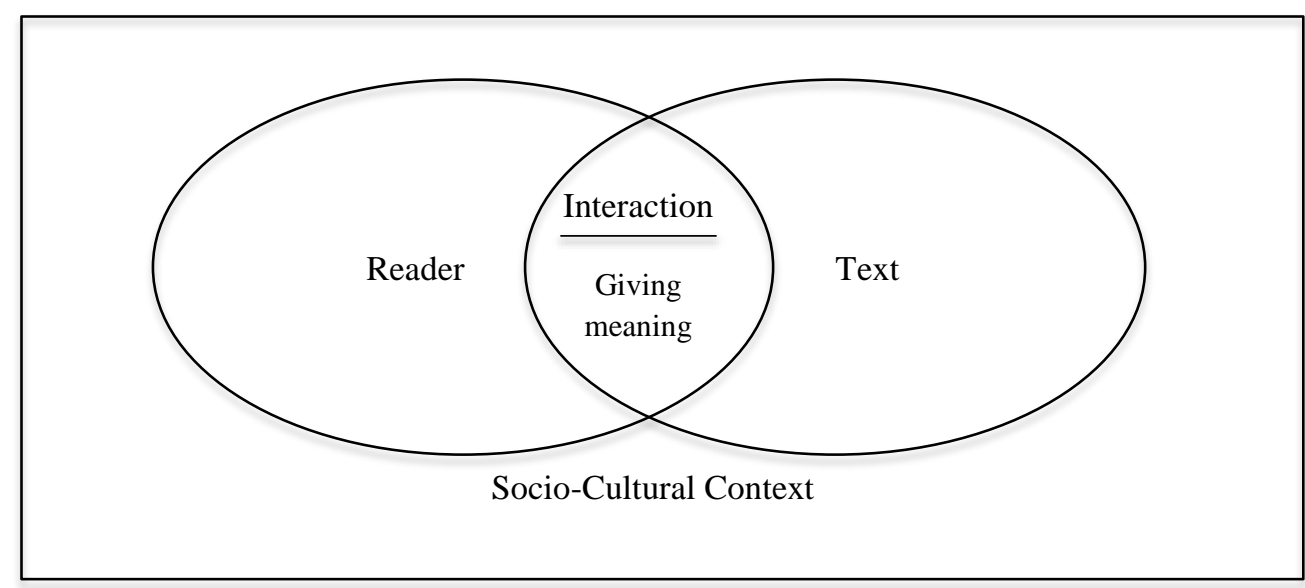

Figure 1. Reading comprehension

Accounting faculty have acknowledged the importance of reading comprehension in their students' learning, focusing their research on students' reading comprehension of textbooks (Adelberg \& Razek, 1984; Bargate, 2012; Cornachione, 2004; Raabe, K.C. Stevens, W.P. Stevens, 1984). Financial reporting students studying solely from textbooks, however, risk referring only to interpretations of IFRS, rather than mastering IFRS as the primary source (Bargate, 2012, Janse van Rensburg, Coetzee \& Schmulian, 2014). An assessment of the students' reading comprehension of IFRS may be necessary for effective teaching and learning of IFRS (Janse van Rensburg et al., 2014). Limited, and mostly dated, exploration of financial reporting students' reading comprehension of primary sources considers selected statements of US GAAP (Adelberg, 1982; Stead, 1977; W.P. Stevens, K.C. Stevens, Raabe, 1983), Government Accounting Standards (GASB) (Shaffer, K.T. Stevens \& W.P. Stevens, 1993), Australian GAAP (Patel \& Day, 1996) and more recently the International Accounting 
Standards Board's (IASB) Conceptual Framework for Financial Reporting (Framework) (Janse van Rensburg et al., 2014).

Reading comprehension is affected by the characteristics of the text accessed by the reader, including the content contained therein and the readability thereof (Pardo, 2004). In terms of content, the Framework is not an IFRS and does not define standards for any particular measurement or disclosure issue (IASB, 2010 ${ }^{\mathrm{a}}$ ). The purpose of the Framework is to set out the concepts that underlie the preparation and presentation of financial statements for external users. These concepts form the basis for the development of the detailed principles and rules contained in an IFRS, that support the accounting treatment of particular economic phenomena (Figure 2 and Figure 3) (Coetzee \& Schmulian, 2012).

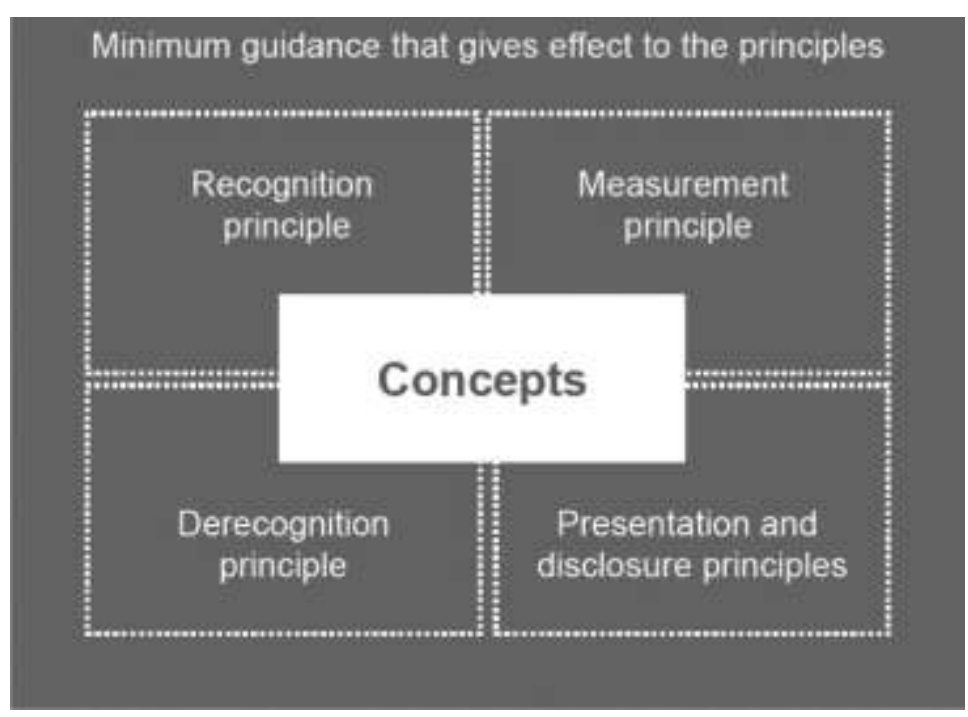

Figure 2. Principle-Based Standard (Source: IASB, 2010 ${ }^{\mathrm{b}}$ ) 


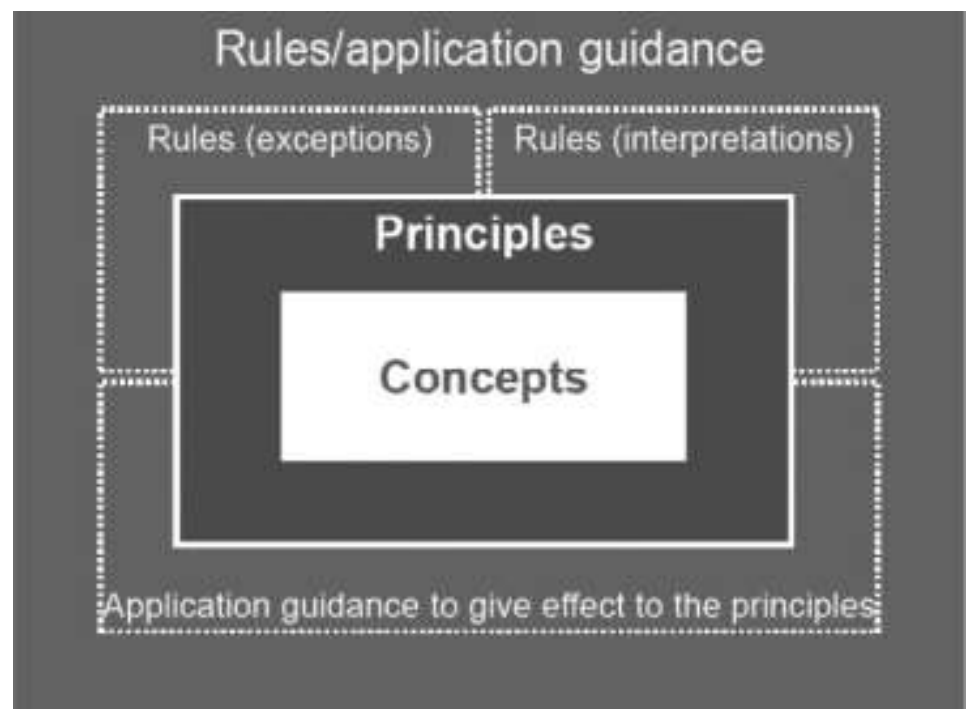

Figure 3. Rules-Based Standard (Source: IASB, 2010 ${ }^{\mathrm{b}}$ )

Readability of text is dependent on the word difficulty (semantic factor) and the sentence length (syntactic factor) of that text (Williamson, 2008). Readability is passive and textcentered and can be determined by objective readability measures, such as Flesch (Jones \& Smith, 2014). The Flesch reading ease score $\left(\right.$ FRES) ${ }^{1}$ of the Framework (FRES=23) is 'very difficult' to read (reading scores of less than 30) (Coetzee, Schmulian \& Cloete, 2014). The FRES of IAS 2, Inventories (FRES=33) and FRES of IAS 16, Property, Plant and Equipment (FRES=31) are, however, 'difficult' to read (reading scores of between 30 and 49). Given the differences in, inter alia, the content and readability of the text of the Framework and IFRS, financial reporting students' reading comprehension of the Framework may, therefore, not be generalised to their reading comprehension of IFRS. Given the differing content and readability of the concepts in the Framework and the prescriptive accounting principles and rules contained in IFRS, differences in reading comprehension may be expected between the Framework and IFRS.

\footnotetext{
${ }^{1}$ The Flesch reading ease score has long been favored as a valid measure of readability in accounting communication literature (Stone \& Parker, 2013). The score is based on the syllables per word and average words per sentence.
} 
Reading comprehension is also affected by the reader's abilities, attributes and motivation (Butcher \& Kintsch, 2003; Fletcher, 1994; Narvaez, 2002; Pardo, 2004; Rayner, Foorman, Perfetti, Pesetsky \& Seidenberg, 2001). A reader's motivation is a consequence of their interest, emotion and persistence in reading the text, while a reader's abilities and attributes are influenced by the reader's socio-cultural environment and understanding of the world (Pardo, 2004). A reader's environment and understanding is formed by their culture. Culture, broadly defined, may encompass, inter alia, gender, language and race (Coetzee, Schmulian \& Kotzé, 2014; Fletcher, 1994; Pardo, 2004; Reynolds, Taylor, Steffensen, Shirey \& Anderson, 1982), although race may be little more than biological fiction (Hammond, Clayton \& Arnold, 2009). The socio-cultural context may be further represented by an individual's schooling environment, as indication of the socio-economic level of the community in which the student is situated (Coetzee, Schmulian \& Kotzé, 2014).

The point at which the reader and the text interact, is the point at which meaning is extracted from the text and comprehension occurs (Pardo, 2004). A student's background knowledge pertaining to the content of the text, may influence the student's ability to comprehend that text (Best, Rowe, Ozuru \& McNamara, 2005; Butcher \& Kintsh, 2003; Compton, Miller, Elleman \& Steacy, 2014; Schallert \& Martin, 2003). In the comprehension of new information, schema theory aids in the understanding of the role of an individual's pre-existing ideas and information (schema) developed through their own life experiences (Anderson, 2005; McVee, Dunsmore \& Gravelek, 2005; Slavin, 1988; Widmayer, 2005). Any new information is given meaning according to how this information fits into existing schema (Christensen, 2006; Widmayer, 2005). A positive correlation exists between a reader's knowledge level and reading comprehension and retention (Compton et al., 2014; Kendeou \& van den Broek, 2007). Such is the strength of this correlation that it has been suggested that knowledge has a primary role in reading comprehension (Cain \& Parrila, 
2014). Consequently, background knowledge may assist even the poorest of readers in compensating for their poor reading ability and enhance their ability to comprehend the text (Compton et al., 2014).

Given that reading comprehension is affected by traits of the reader within a socio-cultural context, this gives rise to the Research Question:

RQ: Are there differences in students' reading comprehension of IFRS in a financial reporting class with a heterogeneous student cohort?

To explore these differences, this paper expands on that of Janse van Rensburg et al. (2014) through performing a differentiated replication ${ }^{2}$ of their study of South African financial reporting students' reading comprehension of the Framework. The diversity of students in South Africa provides the opportunity for such exploration. Given the increase of culturally diverse accounting classrooms globally, the findings of this study may be of interest in other multicultural environments, particularly where students also have diverse traits and have to comprehend learning material in a second language.

\section{Evaluating Reading Comprehension}

Reading comprehension is often evaluated using the Cloze procedure (Taylor, 1953, 1956, 1957; Bormuth, 1968) across a variety of texts, for example, accounting textbooks (Raabe et al., 1984; K.C. Stevens, K.T. Stevens \& W.P. Stevens, 1993; Cornachione, 2004; Bargate, 2012), authoritative accounting pronouncements (Stevens et al., 1983; Adelberg \& Razek, 1984) and a conceptual framework of accounting (Janse van Rensburg et al., 2014). The interaction between the language competence and prior knowledge of a reader and the authors' intended communication forms the foundation of the Cloze procedure (Bormuth,

\footnotetext{
${ }^{2}$ A differentiated replication is deliberate or known variation on a major aspect of a study with the aim of extending the known range of conditions for which the result may hold true (Lindsay \& Ehrenberg, 1993).
} 
1966). It has therefore been suggested that the Cloze procedure is the "criterion of choice" (Klare, 1988, p.24) for assessing adult reading comprehension, as opposed to passive measures of readability, such as Flesch, which ignore the interaction between a reader and the text (Stevens et al., 1993). Correlations between Cloze scores and scores on other forms of reading comprehension tests, including question answering tests, recall measures, oral passage reading tests (L.S. Fuchs, D. Fuchs \& Hamlet, 1988), mazes (Jenkins \& Jewell, 1993; Williams, Ari \& Santamaria, 2011) and true and false comprehension tests (Greene, 2001) demonstrate the reliability of the Cloze procedure as a measure for evaluating reading comprehension.

There is some criticism of the Cloze procedure (Carlisle \& Rice, 2004; Farr \& Carey, 1986; Jones, 1997; Pearson \& Hamm, 2005). It has been suggested that the Cloze procedure is sensitive to decoding and word level processes and not higher-order comprehension (Keenan, Betjemann \& Olson, 2008; Nation \& Snowling, 1997). Evidence has, however, been presented to contest this (Gellert \& Elbro, 2013; Tabatabaei \& Mirzaei, 2014). Despite the criticism, the Cloze procedure provides instructors with a "very teacher-friendly" (Chatel 2001, 3) and "very helpful" indication of their students' general reading proficiency (Hadley and Naaykens, 1999, 64; Klapwijk, 2013) and allows for the exploration of demographic differences in students' reading comprehension (Janse van Rensburg et al., 2014). Diagnostically, the Cloze procedure can effectively determine how students extract the meaning of the text from the context of a sentence or paragraph. Thereafter the same text can be used instructionally, making the Cloze procedure a "truly multipurpose strategy" (Chatel, 2001, 3). The Cloze procedure can be applied to any type of text, as long as the text is well written (Booth, 1998, 71).

The Cloze procedure requires the reader to complete a task that involves the 'clozing' of an argument, either by selecting from three word choices in the maze format or by filling in a 
blank in the open-ended format. Evidence of a high co-variance between the scoring of maze and open-ended Cloze has been provided (Williams et al., 2011). In accounting literature, open-ended Cloze appears to be favoured (Bargate, 2012; Cornachione, 2004; Janse van Rensburg et al., 2014; Stevens et al., 1993). Benchmark comprehension levels for the Cloze procedure were established by Bormuth $(1968,1969)$ and Rankin and Culhane (1969) (Table 1). Readers at the Independent level (scores between 58\% and 100\%) are able to cope with the text without assistance. The Instructional level (scores between $44 \%$ and 57\%) represents readers who are able to cope with the text with some assistance. Readers at the Frustration level (scores between $0 \%$ and $43 \%$ ), find it difficult to cope with and access the specific text.

Table 1. Benchmark comprehension levels for the Cloze procedure

\begin{tabular}{|l|l|}
\hline Cloze score & Level \\
\hline $0 \%-43 \%$ & Frustration level - language is difficult for readers to cope with \\
\hline $44 \%-57 \%$ & Instruction level - readers are able to cope, but some assistance is required \\
\hline $58 \%-100 \%$ & Independent level - readers are able to cope with the language \\
\hline
\end{tabular}

(Bormuth (1968, 1969) and Rankin and Culhane (1969))

\section{Method}

In exploring demographic differences in financial reporting students' reading comprehension, this study replicated the use of the Cloze procedure adopted by Janse van Rensburg et al. (2014). The Cloze procedure was applied to two asset-related standards IAS 2, Inventories (IAS 2) (IASB, 2003 ${ }^{\mathrm{b}}$ ) and IAS 16, Property, Plant and Equipment (IAS 16) (IASB, 2003 ${ }^{\mathrm{c}}$ ). Assets, as an element, have conceptual primacy in financial reporting in that the definitions of all other elements (liabilities, equity, income and expenses) are 'anchored in the asset definition' (Barth, 2008, p. 1167). Therefore, together with liabilities, assets are considered to be one of the 'building blocks' of IFRS financial reporting (Wells, 2011). In addition, it is submitted that the inventories and property, plant and equipment line items constitute a material part of the asset section in many entities' statement of financial position. These asset 
standards are, therefore, considered to be fundamental topics in the teaching and learning of IFRS. Their significance in this respect is enhanced when it is considered that these two standards also permeate through to other topics ${ }^{3}$.

Two passages of IAS 2 and IAS 16 were randomly selected from each pronouncement. The selected passages were taken from paragraphs representing $12.8 \%$ of the total text of IAS 2 (5 of the 39 paragraphs) and $8.75 \%$ of the total text of IAS 16 (7 of the 80 paragraphs). The length of each of these four passages was sufficient to allow fifty deletions per passage (DuBay, 2004), where every fifth word was deleted (Alderson, 1979; Bargate, 2012; Janse van Rensburg et al., 2014; Hartley \& Trueman, 1986). The deleted words were replaced by underlined blank spaces of equal length. The following extracts illustrate the passages, with the deleted words indicated in italic type:

\section{IAS 2:}

\section{Costs of conversion}

The costs of conversion of inventories include costs directly related to the units of production, such as direct labour. They also include a systematic allocation of fixed and variable production overheads_that are incurred in converting materials into finished goods.

\section{IAS 16:}

\section{Subsequent costs}

Under the recognition principle in paragraph 7, an entity does not recognise in the carrying amount of an item of property, plant and a equipment the costs of the day-to-day servicing_ of _ the item. Rather, these costs are recognised in profit

The passages were distributed to all the students enrolled for the first time for a financial reporting course in which they are introduced to IFRS. This course forms part of an

\footnotetext{
${ }^{3}$ These topics include: IFRS 3, Business Combinations (IASB, 2008); IAS 8, Accounting Policies, Changes in Accounting Estimates and Errors (IASB, 2003 $)$; IAS 36, Impairment of Assets (IASB, 2003 ${ }^{\mathrm{d}}$ ) and IAS 40, Investment Property (IASB, $2003^{\mathrm{e}}$ ).
} 
undergraduate professional accounting education programme ${ }^{4}$ at a leading South African university. IAS 2 and IAS 16 are the first IFRS's that these students are exposed to on the course and the passages were distributed to the students at their first contact session for these topics. These topics are presented over the first weeks of the course. The students entering this course have completed a 'bookkeeping' course during which they were exposed to generic accounting terminology. They were not assigned any textbook reading on the respective topics prior to completing the passages. The study's objective was not to test the students' memory. Written instructions on the completion of the passages were included in a covering letter. The written instructions were supplemented by a visual demonstration thereof by an author, being an instructor on the course, to ensure that the students thoroughly understood the procedure (Bargate, 2012). The students were not allowed to refer to the particular IFRS when completing the given passages. A time limit of 15 minutes per passage, thus a total of 30 minutes per selected IFRS, was allocated for the completion of the procedure (Janse van Rensburg et al., 2014). The Cloze procedure does not consider or allow for the effort and motivation (or lack thereof) demonstrated by the students (Bargate, 2012). Further, there can be no absolute assurance that all the students attempted the test with the same commitment.

\subsection{Target Population}

Demographic data of the respondent students $(n=375,87 \%)$ were collected simultaneously with the completion of the passages. The demographic profile of these respondents is illustrated in Figure 4. Despite South Africans communicating in any of 11 official languages $^{5}$ at home (first language), instruction at university level is only in Afrikaans ${ }^{6}$

\footnotetext{
${ }^{4}$ For purposes of this paper, 'professional accounting education' is defined as accounting programmes, which have as their primary objective the graduating of students who qualify to enter the professional accountancy examinations of a professional accounting body.

${ }^{5}$ The 11 official South African languages spoken at home are Afrikaans, English and 9 African languages (Sesotho, isiZulu, isiXhosa, Setswana, isiNdbele, Siswati, TshiVenda, XiTsonga and Sepedi).
} 
and/or English. The language of instruction for this course is either Afrikaans $(n=111)$ or English (n=264). The Afrikaans instruction group comprises exclusively of Afrikaans first language students from the White $(n=110)$ and $\operatorname{Other}^{7}(n=1)$ population groups. The students receiving instruction in English consist of African $(n=150)$, White $(n=79)$ or Other $(n=35)$ students, who speak either English $(n=138)$, Afrikaans $(n=21)$ or an African ${ }^{11}$ language $(\mathrm{n}=105)$ as a first language. Course materials and components (e.g. tutorials, textbooks and assessments) are generally available in both Afrikaans and English. IFRS is, however, not translated into Afrikaans or any of the African first languages. All students are expected to study from the English version of IFRS as their primary source. It is therefore particularly important to explore the English second language students' reading comprehension of their primary study source. Accordingly, the selected passages from IFRS were provided to all students in English, as is customary in their education process, regardless of the student's first or instruction language.

The respondent students have entered the university from secondary schools situated in differing socio-economic environments. The South African government assigns a poverty score $^{8}$ to schools, categorising the schools into quintiles. Quintile 5 represents schools situated in higher socio-economic communities, while quintile 1-4 represents poorer communities. Although the racial divides of the country's past have been erased, the legacy of Apartheid remains evident in that the lower quintile schools generally remain poorly resourced and underfunded former African schools, while quintile 5 represents well-

\footnotetext{
${ }^{6}$ Afrikaans is a West Germanic language which is spoken natively in South Africa; with approximately six million native speakers in South Africa, or 13.3 per cent of the population, it is the third most spoken mother tounge in the country (De Swaan, 2001).

${ }^{7}$ The Other population group comprises of Asian, Chinese, Indian and Mixed-race students. The Mixed-race population group originates from at least five different paternal and maternal populations (Khoisan, Bantus, Europeans, Indians, and Southeast Asians).

${ }^{8}$ The poverty score is calculated with reference to the average household income dependency ratio and the literacy rate of the community (HSRC, 2009). This poverty score determines the government funding received by the school in terms of the South African Schools Act (84/1996).
} 


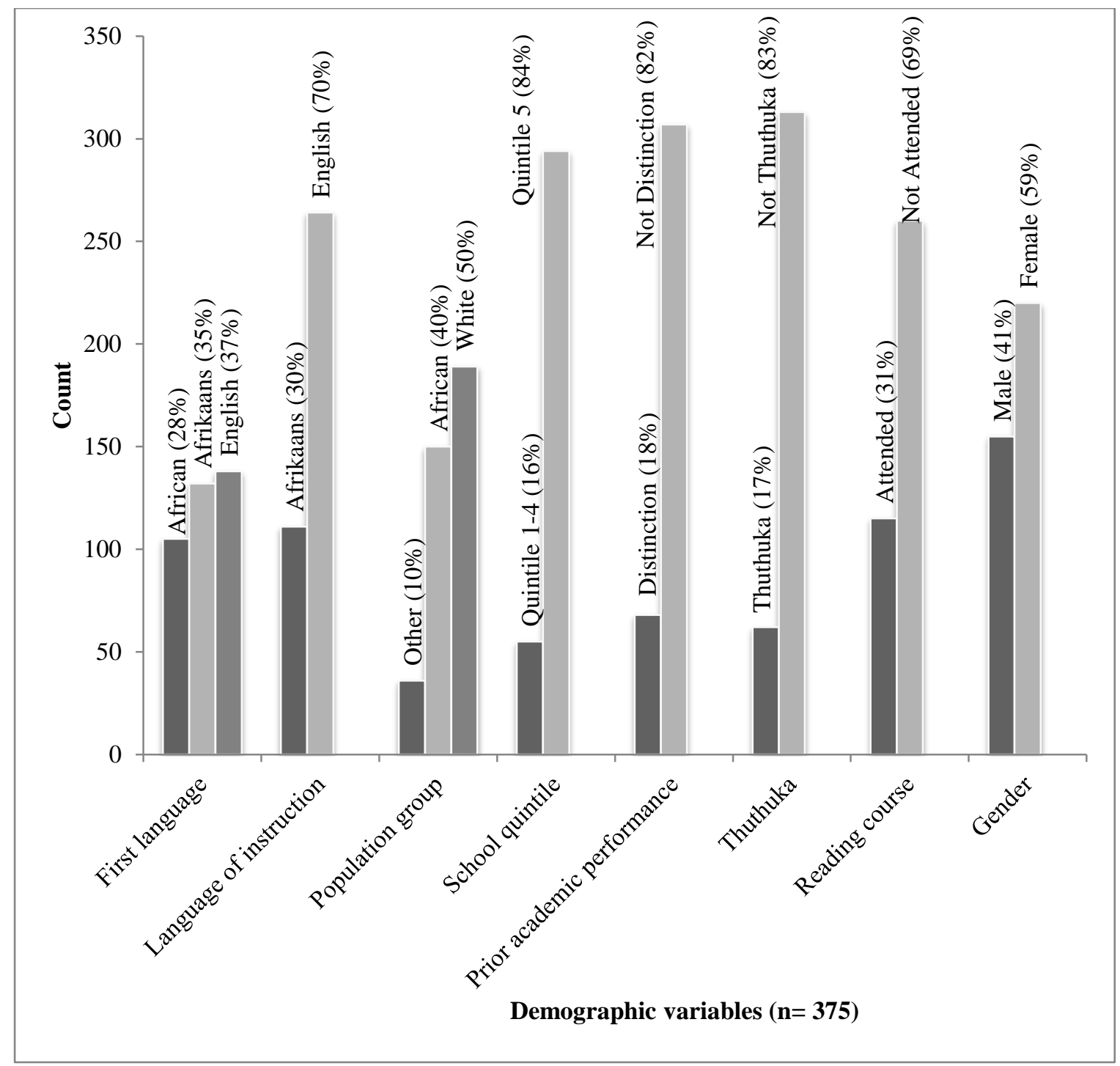

Figure 4. Demographic profile

resourced and funded former White schools. These quintiles therefore largely continue to reflect the quality of the education provided (Coetzee, Schmulian \& Kotzé, 2014; K. Sartorius \& B. Sartorius, 2013; Spaull, 2013). The majority of students $(n=294)$ attended quintile 5 schools $^{9} .68$ students achieved a distinction in the first year 'bookkeeping' course. Some students $(n=62)$ have received additional academic assistance in the form of the Thuthuka special support programme. This programme, funded primarily by the accounting profession in South Africa, offers students from disadvantaged communities, financial

926 students did not complete this information, therefore $n=349$ for this variable. 
support and academic interventions, including additional exposure to financial literacy (see Barac, 2015). Further, 115 students have attended a reading course ${ }^{10}$ while 260 have not. Finally, female students $(n=220)$ were in the majority.

\subsection{Regression}

In response to the Research Question, an exploratory ordinary least-squares (OLS) regression was used to simultaneously explore the association between several demographic variables and reading comprehension (RC). The demographic variables explored in this study are first language (FirstLang), language of instruction (InstructLang), population group (PopGroup), school quintile (SchoolHigh), prior academic performance (AcadPerf), enrolment in the Thuthuka programme (Thuthuka), the attendance or not of a reading course (ReadCourse) and gender (Gender).

$\mathrm{RC}=\alpha+\beta_{1}$ FirstLangAfrik $+\beta_{2}$ FirstLangAfric $+\beta_{3}$ InstructLang $+\beta_{4}$ PopGroupAfric + $\beta_{5}$ PopGroupOth $+\beta_{6}$ SchoolHigh $+\beta_{7}$ AcadPerf $+\beta_{8}$ Thuthuka $+\beta_{9}$ ReadCourse $+\beta_{10}$ Gender $+\mathcal{E}$

$\mathrm{RC}$ is the students' reading comprehension, as the dependent variable, and represents the students' Cloze reading comprehension scores. FirstLangAfrik equals 1 for Afrikaans first language and 0 for not Afrikaans first language. Similarly, FirstLangAfric equals 1 for African first language and 0 for not African first language. The coefficients indicate whether the reading comprehension scores for these groups of students are different to the English first language students (FirstLangAfrik and FirstLangAfric both equal 0). Readers have demonstrated lower reading comprehension when reading in their second language as apposed to their first language (Bargate, 2012; Janse van Rensburg et al., 2014; Pasquarella, Gottardo \& Grant, 2012). A negative relationship is therefore expected between first

\footnotetext{
${ }^{10}$ Students may voluntarily attend reading courses with the intention of, inter alia, increasing their reading speed, comprehension, concentration, retention and recall skills. Reading courses usually involve the assessment of current reading speed and comprehension levels together with the identification of poor reading habits. The outcome of such a course usually results in an increase in reading speed and comprehension levels as well as the introduction of improved reading habits (Janse van Rensburg et al., 2014).
} 
language (FirstLang) and the Cloze reading comprehension scores. However, regardless of the first language of communication, receiving instruction in the language of the document to be read may enhance reading comprehension (Janse van Rensburg et al., 2014). InstructLang equals 1 if students receive instruction in English and InstructLang equals 0 if students receive instruction in Afrikaans. A positive relationship is expected between language of instruction (InstructLang) and the Cloze reading comprehension scores. There were no expectations for the signs of the coefficients for the population group (PopGroup) variables, being African, White and Other. PopGroupAfric equals 1 for African students and 0 for not African students. Similarly, PopGroupOth equals 1 for Other population students and 0 for not Other population students. The coefficients indicate whether the reading comprehension scores for these groups of students are different when compared to the White students (PopGroupAfric and PopGroupOth both equal 0). SchoolHigh equals 1 for students who attended schools assigned to quintile 5. This coefficient indicates whether the Cloze reading comprehension scores for students from quintile 5 schools are different from those students who attended quintile 1-4 schools (SchoolHigh equals 0). Quintile 5 schools are better resourced, in terms of, for example, computers, library books and teachers, providing greater opportunity for the development of literacy skills (Bhorat \& Oosthuizen, 2008). A positive relationship is therefore expected between the schooling environment (SchoolHigh) and the Cloze reading comprehension scores. The proxy used for prior academic performance (AcadPerf) is the students' percentage mark for their first year 'bookkeeping' course. As background knowledge may influence reading comprehension, the sign of the coefficient for AcadPerf is expected to be positive. Thuthuka equals 1 for students that are enrolled in the Thuthuka programme. A positive relationship was expected between the enrolment in the Thuthuka programme and the Cloze reading comprehension scores. A positive relationship is further expected between the reading course attendance (ReadCourse) and Cloze reading 
comprehension scores (Janse van Rensburg et al., 2014) (ReadCourse equals 1 if a reading course has been attended and ReadCourse equals 0 if no reading course has been attended). A positive relationship is also expected between gender and the students' Cloze reading comprehension scores (Gender equals 1 for female and 0 for male). Female students' reading comprehension may generally exceed that of their male counterparts (Bray \& Barron, 2003; Broom \& Jewson, 2013; Janse van Rensburg et al., 2014), although some association between gender and age has been suggested. Females demonstrate better reading comprehension as children or adolescents (Logan \& Johnston, 2010; Lynn \& Mikk, 2009), while gender differences in reading comprehension for adults appear less pronounced (Hannon, 2014; Hyde \& Linn, 1988).

\section{Results and Discussion}

The mean Cloze reading comprehension score ${ }^{11}$ for the selected IFRS's, namely IAS 2 and IAS 16, is at the Instructional level (M=54.07; sd=8.024) (Figure 5). Analysis of the distribution of the score revealed that $53.6 \%$ of the students read at the Instructional level, whilst 36.5\% read at the Independent level. Similar results were reported for the Framework (Janse van Rensburg et al., 2014). The majority of the respondent students may therefore require some assistance to access and decode the content of the selected IFRS's, preceding the development of their ability to evaluate, critique and apply the content thereof.

The results of the exploratory multivariate analysis (Table 2), suggest that the variables for prior academic performance ( $\mathrm{t}$-statistic $=6.954 ; \mathrm{p}=0.000)$, Afrikaans first language ( $\mathrm{t}-$ statistic $=-1.684 ; \mathrm{p}=0.093)$, language of instruction ( $\mathrm{t}$-statistic $=1.923 ; \mathrm{p}=0.055)$, and enrolment

\footnotetext{
${ }^{11}$ The results are reported for the total Cloze reading comprehension scores of IAS 2 and IAS 16 combined. The results between the separate passages within each of these standards and between the standards are highly correlated (untabulated) with no statistically significant difference in the mean scores of each passage (untabulated). The results for each standard are also highly correlated to the total combined Cloze reading comprehension score (untabulated).
} 


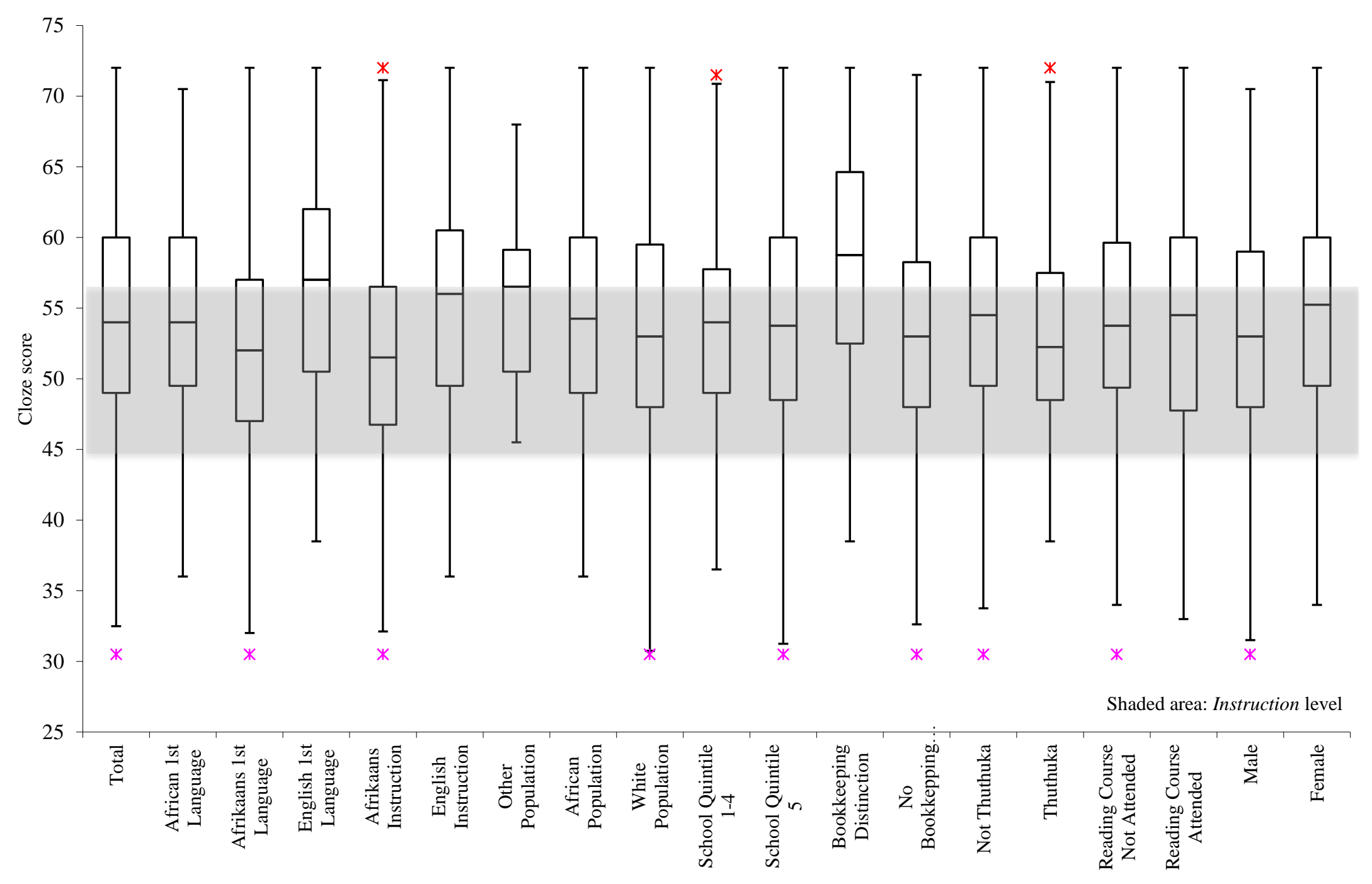

Figure 5. Cloze score box plot 
in the Thuthuka programme (t-statistic $=-2.511 ; \mathrm{p}=0.013$ ) are statistically significant in differentiating between the mean Cloze reading comprehension scores within each of these demographic groups. The results confirm the expectation for the direction of the association in each instance, with the exception of the Thuthuka programme.

The statistically significant association, between prior academic performance (as proxy for background knowledge) and the reading comprehension score, offers support for literature that suggests background knowledge is important to achieve a deeper understanding of text (Cain \& Parrila, 2014; Compton et al., 2014) and extends these findings to financial reporting education. Students that achieved a distinction in the prior year 'bookkeeping' course, scored a mean of 58.14 , compared to a mean of 53.17 scored by students who did not achieve a distinction. The majority of distinction students read at the Independent level, while $32 \%$ of the non-distinction students scored at this level.

As illustrated in Figure 6, the difference between the mean score of those students receiving instruction in Afrikaans $(\mathrm{M}=51.21)$ and those receiving instruction in English $(M=55.27)$ is statistically significant. Within the English instruction group, there are English, African and Afrikaans first language students. The mean score of the English first language students $(M=56.64)$ does not differ statistically from the mean score of the African first language students $(M=53.72)$, but does, however, differ statistically from the mean score of the total Afrikaans first language students $(M=51.66)$. The majority of the Afrikaans first language students are in the Afrikaans instruction group. Therefore, despite African and Afrikaans students reading the document not in their first language, receiving instruction in English appears to assist the African students' reading comprehension of IFRS. 


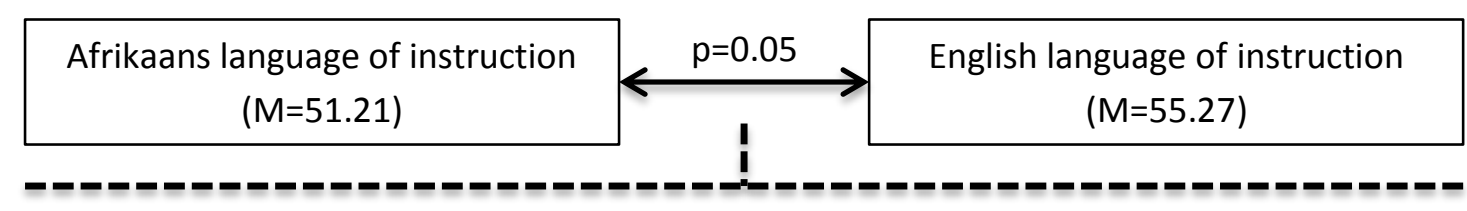

First language

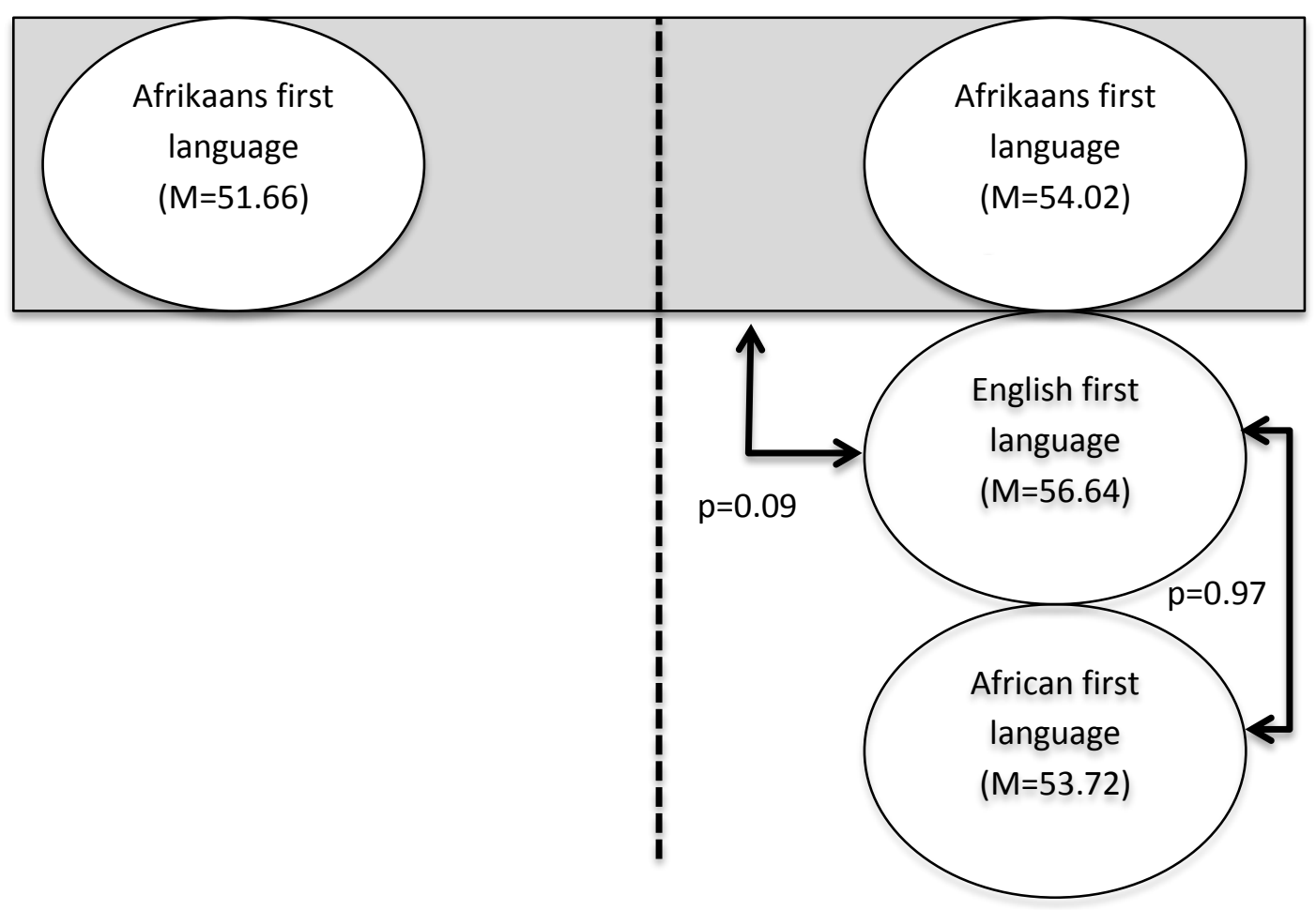

Figure 6. Interaction between instruction language and first language

Students enrolled in the Thuthuka programme were exposed to additional interventions at first year level. However, these students' mean score $(\mathrm{M}=53.02)$ is still significantly lower than the mean score of students not enrolled in the Thuthuka programme (M=54.27). The aim of the Thuthuka programme is to assist students from disadvantaged backgrounds in their education towards qualifying as professional accountants. Their lower mean reading comprehension score may suggest that despite the assistance provided throughout the first year 'bookkeeping' course, continued support in the development of the students' reading comprehension of IFRS is required during the introductory course to IFRS. 
The gender, population, school quintile, and reading course variables were not statistically significantly associated with the reading comprehension score. The mean score of female students $(M=54.70)$ was, however, higher than the mean score of male students $(M=53.16)$, as predicted. The 36 students in the Other population group had a mean score of 55.54, compared to African students $(M=54.24)$ and White students $(M=53.65)$. Contributing to the White students' mean score being less than the African students' mean score, is that 132 of the 189 White students were Afrikaans first language students. Students from quintile 5 schools had a mean score of 53.93, compared to a mean score of 53.32 for students from quintile $1-4$ schools $^{12} .10 \%$ of the students from quintile 5 schools read at the Frustration level, compared to $13 \%$ of the students from quintile 1-4 schools. Also, more students from quintile 5 schools (37\%) read at the Independent level than students from quintile 1-4 schools (33\%). In contrast with the finding by Janse van Rensburg et al. (2014), attendance of a reading course was not statistically significantly associated with an increased reading comprehension. Students who had attended a reading course and those who had not, scored a mean of 54 .

\footnotetext{
${ }^{12}$ Quintile 1 to 4 schools were combined, as the individual quintiles were too small to allow for meaningful statistical analysis.
} 


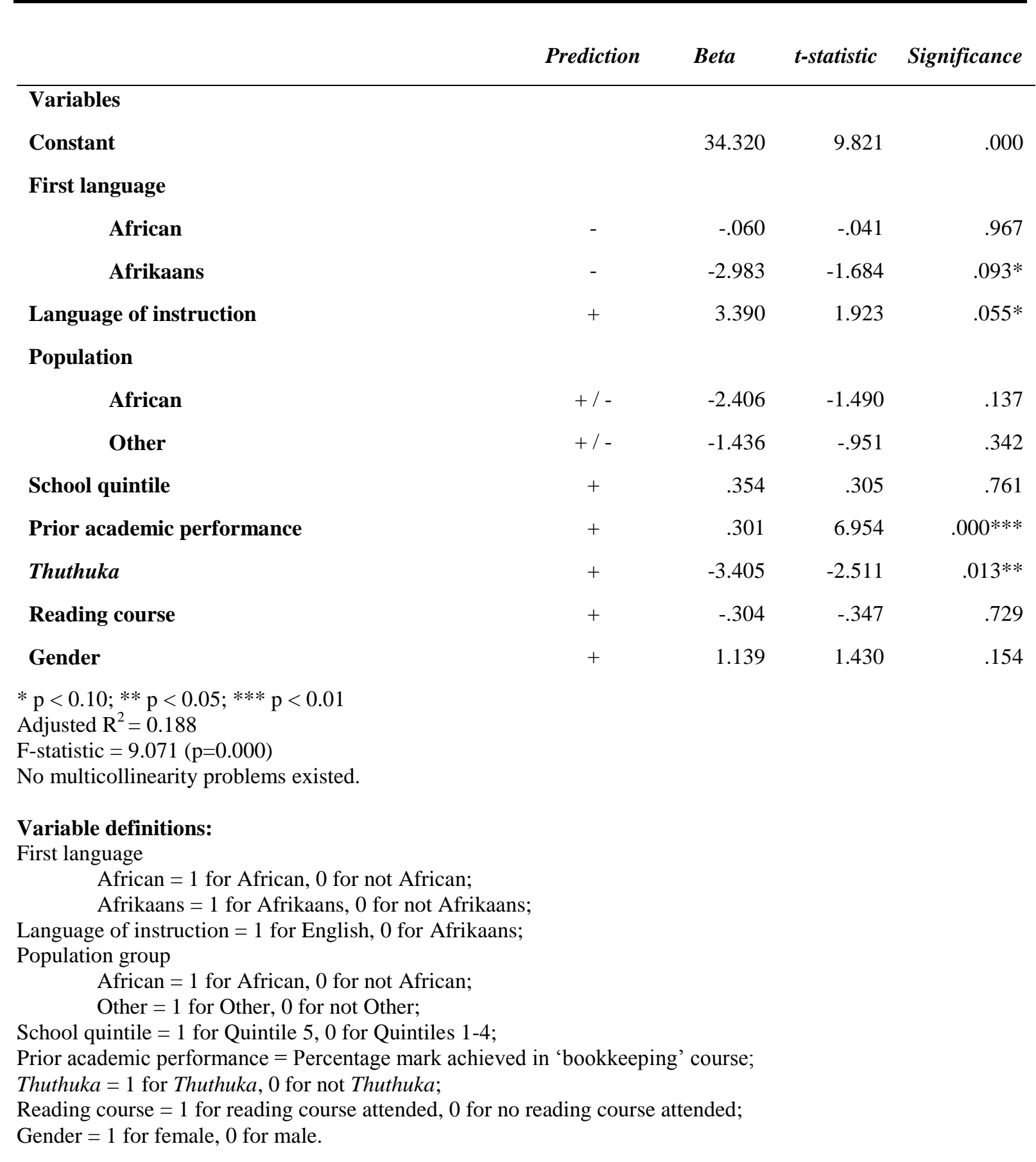

\section{Developing Reading Comprehension}

Although a full discussion of developing reading comprehension is beyond the scope of this study, where comprehension difficulties are identified, instructors need to distinguish between 'language-based comprehension difficulties', including those experienced by 
students acquiring English as a second language (Janse van Rensburg et al., 2014; Zoghi, Musthapa, Rizan \& Maasum, 2010) and 'background knowledge-based comprehension difficulties', for example where students do not have the necessary knowledge to form the required inferences needed to comprehend text (Compton et al., 2014; Elbro \& Buch-Iverson, 2013).

\subsection{Language-based Comprehension Problems}

In addressing language-based comprehension problems, such as those possibly faced by the Afrikaans students in this study, instructors may consider explicit instruction of, inter alia, grammar and language rules (Koda, 2010). Instructors may need to make a concerted effort to integrate the explicit teaching of words and phrases during class discussions or through writing assignments (Duke, Pearson, Strachan \& Billman, 2011; NAS, 2012). Alternatively, a more subtle approach may be adopted to implicitly develop students' language skills (DeKeyser, 2003; Stanat, Becker, Baumert, Lüdtke \& Eckhardt, 2012). Implicit development may, for example, occur through encouraging students to read the financial press (Janse van Rensburg et al., 2014). It is widely believed that the more you read, the better you read (Duke et al., 2011; Guthrie, 2004). To increase the volume of reading experiences by accounting students, instructors may provide different additional accounting texts to their students.

Developing the skill of decoding could also elevate students' reading comprehension (NAS, 2012). Focused classroom discussions or videos (Duke et al., 2011; Lei, Rhinehart, Howard \& Cho, 2010; IFRS Rookies, 2015) on specific topics could develop this skill. For example, instructors may read complex sections from IFRS and subsequently explain its meaning and context. An example of a paragraph from IAS 16 addressed in a video, together with a visual representation thereof, is included in Figure 7. 

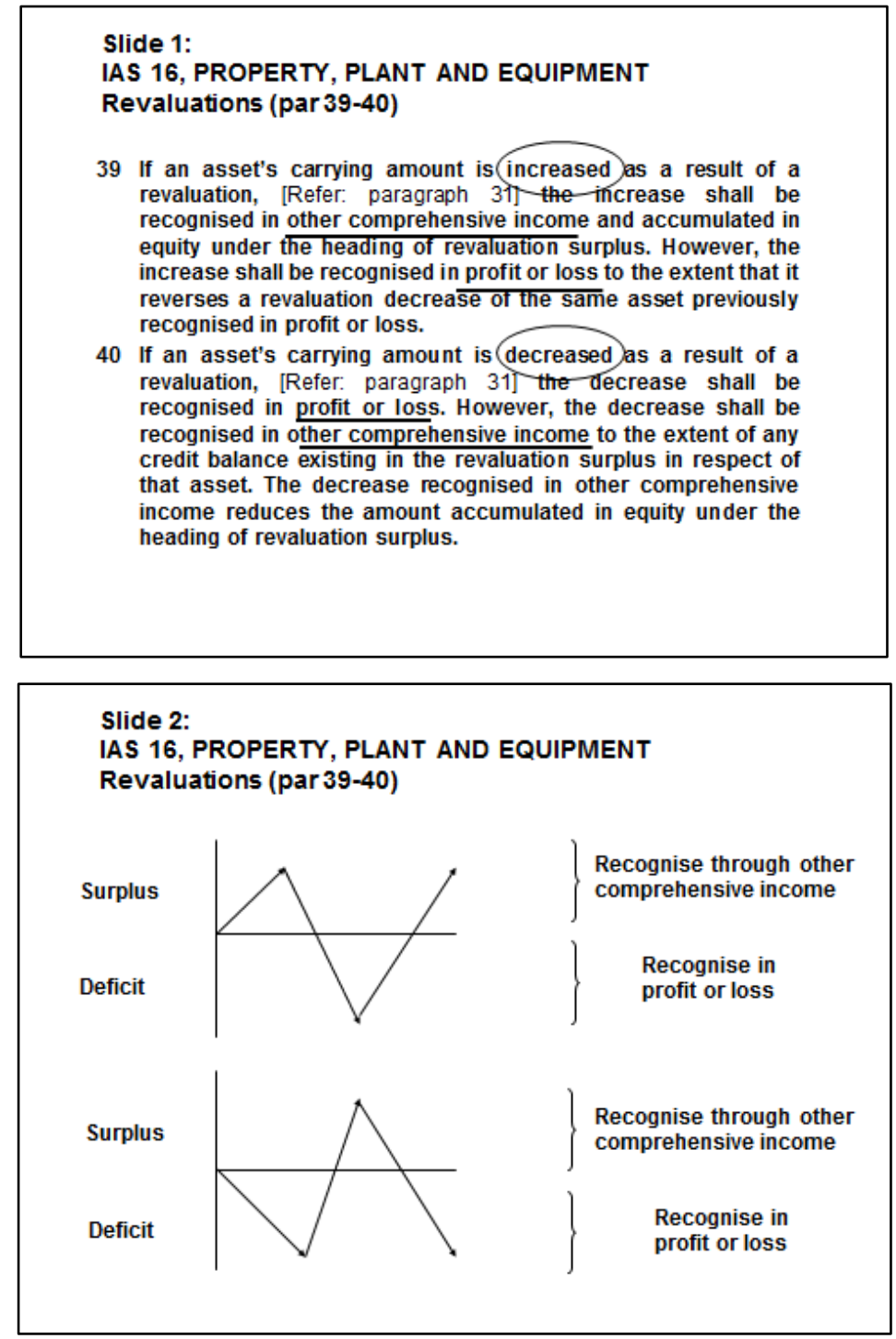

Figure 7. Reading comprehension of IAS 16.39 and 40 (adapted and emphasis added) (Source: IFRS Rookies, 2015)

\subsection{Background Knowledge-based Comprehension Problems}

In developing reading comprehension, poor language skills may be compensated for by elevating students' background knowledge (Compton et al., 2014; Kim \& Anderson, 2011; Lei et al., 2010). Instructors may need to consider whether students' background knowledge is inadequate (Hirsch, 2003), is wrong - resulting in erroneous interpretation and poor memory (Kendeou \& van den Broek, 2007), or if the student has the relevant background knowledge but is unable to use it (Oakhill \& Cain, 2007; Elbro \& Buch-Iversen, 2013). The 
latter presents a particular challenge to instructors to identify and, if necessary, remedy. Two interventions to consider for background knowledge-based comprehension development are content instruction and strategy instruction (McKeown, Beck \& Blake, 2009). Content instruction employs open, meaning-based questions about the text, to focus students' attention on the content (McKeown et al., 2009). Strategy instruction teaches students specific procedures to employ during the reading of text to guide their access to the text (McKeown et al., 2009) and may include making use of concept mapping or encoding in the process of summarising key concepts (Kim \& Anderson, 2011). An example of such a concept map of IAS 16 is included in Figure 8.

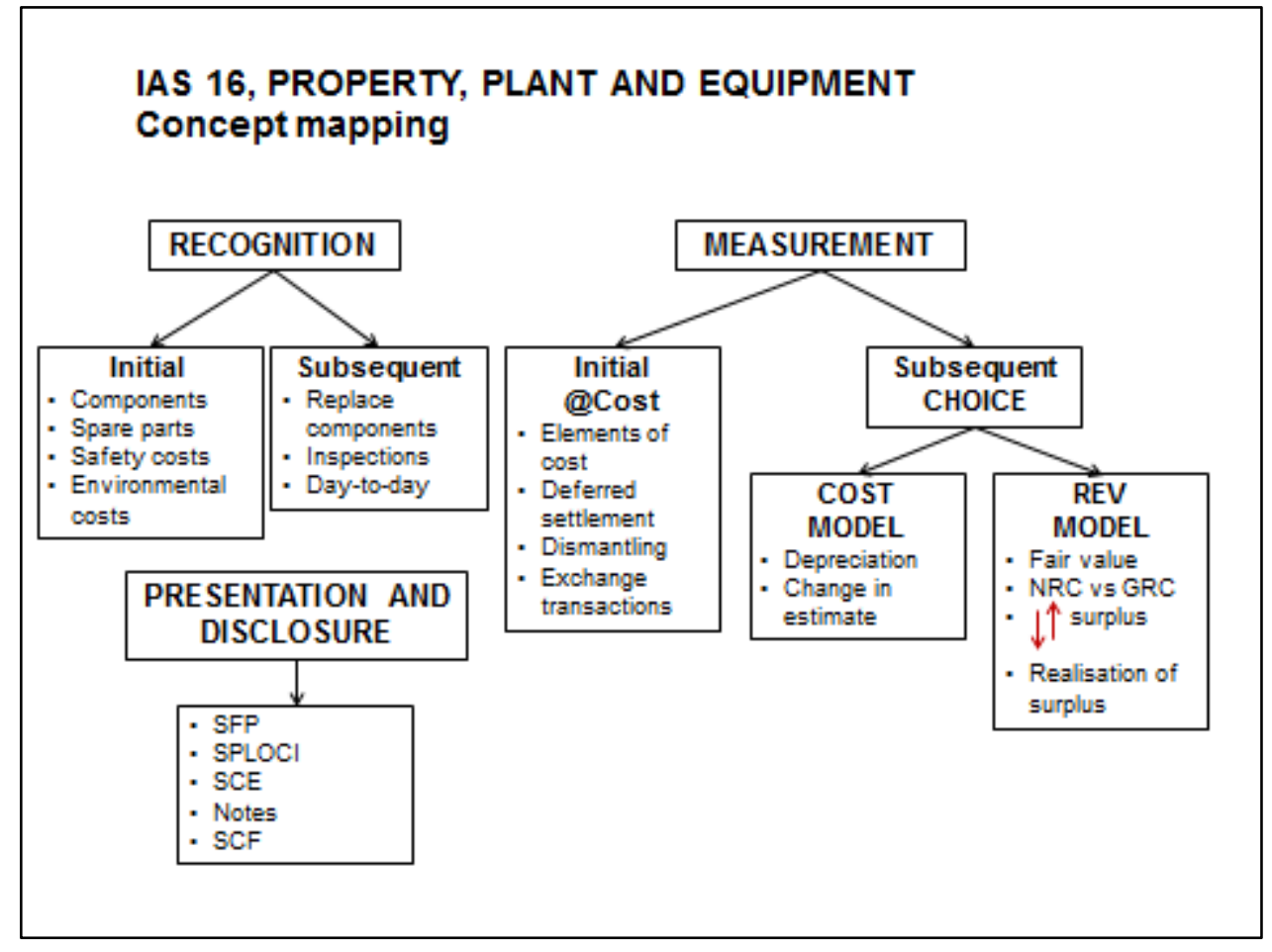

Figure 8. Concept map of IAS 16 (Source: IFRS Rookies, 2015)

\subsection{Differentiated Instruction}

The generalised application of a particular intervention in a heterogeneous class may not be appropriate to develop reading comprehension. As reading comprehension is dependent on a 
reader's individual attributes and abilities, instructors may need to embrace differentiated instruction. Differentiated instruction is an approach that assumes there is a diversity of students in every classroom and all those students can be reached if a variety of methods and activities are used (Tomlinson, 2000). It is a changed instruction method that assists students with diverse academic needs and learning styles to master the same challenging academic content (Tomlinson, 2000). It involves varying materials, teaching processes and assessments to meet specific student groupings' needs and learning styles (Good, 2006). The purpose of differentiated instruction is to ensure that all students, regardless of the level of diversity, achieve a similar outcome (Good, 2006).

In a financial reporting class with a heterogeneous cohort, where differences in reading comprehension abilities have been identified between demographic groupings, the adoption of differentiated instruction could be meaningful for purposes of developing each demographic grouping's particular reading comprehension. For example, interventions that could, inter alia, be implemented for the reported student cohort, include language-based comprehension interventions for the Afrikaans students and background knowledge-based comprehension interventions for the students with poorer prior academic performance.

\section{Conclusion}

This study explores differences in students' reading comprehension of IFRS in a South African financial reporting class with a heterogeneous student cohort. Using the Cloze procedure, the combined mean reading comprehension score for IAS 2 and IAS 16 was found to be at the Instructional level. Students reading at this, or the Frustration level, may require assistance to access and decode the content of IFRS. Reading comprehension is influenced by several factors, including the reader's background knowledge and experience. Accordingly this study investigated, through an exploratory multivariate analysis, the association between the students' demographic profiles and their reading comprehension scores. The results 
thereof suggest that prior academic performance, language of instruction, first language and enrolment in the Thuthuka programme are statistically significant in differentiating between the mean Cloze reading comprehension scores of the students. The gender, population, school quintile, and reading course variables were not statistically significantly associated with the mean Cloze reading comprehension scores. The result of this study suggest that where students, in a heterogeneous financial reporting class, require additional assistance to develop their reading comprehension, instructors may need to consider implementing differentiated instruction.

This study does not aim to provide a conclusive indication of financial reporting students' reading comprehension of IFRS. Further, reading comprehension is a complex construct, which may be influenced by several elements (Klapwijk, 2013). The investigation of additional variables, which may influence the financial reporting students' reading comprehension of IFRS, is encouraged. Alternative assessments of reading comprehension may also be employed. Enquiries may also further consider the application of interventions, such as content instruction or strategy instruction, in the financial reporting classroom, as a remedy for any reading comprehension difficulties that students may experience in reading IFRS. 


\section{References}

Adelberg, A.H. (1982). An empirical evaluation of the communication of authoritative pronouncements in accounting. Accounting \& Finance, 22(2), 73-94.

Adelberg, A.H., \& Razek, J.H. (1984). The Cloze procedure: a methodology for determining the understandability of Accounting textbooks. The Accounting Review, LIX(1), 109122.Alderson, J.C. (1979). The effect on the Cloze test of changes in deletion frequency. Journal of Research in Reading, 2(2), 108-119.

Anderson, J. (2005). Cognitive psychology and its implications (6th ed.) New York: Worth.

Barac, K. (2015). Helping Disadvantaged Students: Findings from the Thuthuka Programme. Accounting Education: an international journal, 24(2), 75-101

Bargate, K. (2012). The Readability of Managerial Accounting and Financial Management Textbooks. Meditari Accounting Research, 20(1), 4-20.

Barth, M.E. (2008). Global Financial Reporting: Implications for U.S. Academics. Accounting Review, 83(5), 1159-1179.

Best, R.M., Rowe, M., Ozuru, Y., \& McNamara, D.S. (2005). Deep-level comprehension of science texts: The role of the reader and the text. Topics in Language Disorders, 25, 65.

Bhorat, H., \& Oosthuizen, M. (2009). Determinants of Grade 12 pass rates in the postapartheid South African schooling system. Journal of African Economies, 18(4), 634666.

Booth, D. (1998). Guiding the Reading Process: Techniques and strategies for successful instruction in K-8 classrooms. Pembroke Publishers Limited.

Bormuth, J.R. (1966). Readability: A new approach. Reading Research Quarterly, 1, 79-132.

Bormuth, J.R. (1968). Cloze test readability: criterion reference scores. Journal of Educational Measurement, 5(3), 189-196.

Bormuth, J.R. (1969). Factor validity of Cloze tests as measures of reading comprehension ability. Reading Research Quarterly, IV(3), 358-365.

Bray, G.B., \& Barron, S. (2003). Assessing reading comprehension: The effects of text-based interest, gender and ability. Educational Assessment, 9(3), 107-128.

Broom, Y., \& Jewson, D.D. (2013). The Stanford Diagnostic Reading Test: Assessing English reading comprehension and vocabulary in South Africa. Per Linguam: A Journal of Language Learning, 29(2), 1-16.

Butcher, K.R., \& Kintsch, W. (2003). Text comprehension and discourse processing. Handbook of psychology, 4, (pp. 575-595). New York: Wiley.

Cain, K., \& Parrila, R. (2014). Introduction to the Special Issue. Theories of Reading: What We Have Learned From Two Decades of Scientific Research. Scientific Studies of Reading, 18(1), 1-4.

Carlisle, J., \& Rice, M. (2004). Assessment of reading comprehension. In A. Stone, E. Silliman, B. Ehren, and K. Apel (Eds.). Handbook of language and literacy (pp. 521555). New York, NY: Guilford.

Chatel, R. G. (2001). Diagnostic and instructional uses of the Cloze procedure. New England Reading Association Journal, 37(1), 3. 
Christensen, L.M. (2006). The Psychology Behind Case Briefing: A Powerful Cognitive Schema. Campbell Law Review, 29, 301-323.

Coetzee, S.A., \& Schmulian, A. (2012). A critical analysis of the pedagogical approach employed in an introductory course to IFRS. Issues in Accounting Education, 27(1), 83100.

Coetzee, S.A., Schmulian, A., \& Cloete, M. (2014). The Readability of the Conceptual Framework for Financial Reporting. World Congress of Accounting Educators and Researchers. Florence, Italy.

Coetzee, S.A., Schmulian, A., \& Kotzé, L. (2014). Communication apprehension of South African accounting students: The effect of culture and language. Issues in Accounting Education, 29(4), 505-525.

Compton, D.L., Miller, A.C., Elleman, A.M., \& Steacy, L.M. (2014). Have We Forsaken Reading Theory in the Name of "Quick Fix" Interventions for Children With Reading Disability?. Scientific Studies of Reading, 18(1), 55-73.

Cornachione, E. (2004). Quality of Accounting textbooks: measuring students' comprehension with the Cloze procedure. Paper presented at the Biennial International Research Conference for Accounting Educators, Durban, 30 June-2 July 2004.

DeKeyser, R.M. (2003). Implicit and explicit learning. In C.J. Doughty \& M.H. Long (Eds.), The handbook of second language acquisition (pp. 313-348). Oxford: Blackwell.

De Swaan, A. (2001). Words of the World: The Global Language System. Wiley-Blackwell, Hoboken, NJ.

DuBay, W.H. (2004). The principles of readability. Impact Information, 1-76.

Duke, N. K., Pearson, P. D., Strachan, S.L., \& Billman, A.K. (2011). Essential elements of fostering and teaching reading comprehension. In A.E. Farstrup \& S.J. Samuels (Eds.). What research has to say about reading instruction, 4, (pp. 51-93). Newark, DE: International Reading Association.

Elbro, C., \& Buch-Iversen, I. (2013). Activation of background knowledge for inference making: effects on reading comprehension. Scientific Studies of Reading, 17(6), 435-452.

Farr, R., \& Carey, R.F. (1986). Reading: What can be measured? Newark, DE: International Reading Association.

Fletcher, C.R. (1994). Levels of presentation in memory for discourse, In M.A. Gernsbacher (Ed.). Handbook of psycholinguistics, 589-607.

Fuchs, L.S., Fuchs, D., \& Hamlet, L. (1988). The validity of informal reading comprehension measures. RASE: Remedial and Special Education, 9(2), 20-28.

Gellert, A.S., \& Elbro, A. (2013). Cloze Tests May be Quick, But Are They Dirty? Development and Preliminary Validation of a Cloze Test of Reading Comprehension. Journal of Psychoeducational Assessment, 2013, 31(16).

Good, M. E. (2006). Differentiated Instruction: Principles and Techniques for the Elementary Grades. San Rafael, CA: School of Business, Education, and Leadership at Dominican University of California. Retrieved June, 2, 2015 from: http://files.eric.ed.gov/fulltext/ED491580.pdf

Greene, B.B. (2001). Testing reading comprehension of theoretical discourse with Cloze. Journal of Research in Reading, 24(1), 82-98. 
Guthrie, J. T. (2004). Teaching for literacy engagement. Journal of Literacy Research, 36(1), $1-30$.

Hadley, G. and J. Naaykens. 1999. Testing the test: Comparing SEMAC and Exact Word scoring on the Selection Deletion Cloze. The Korea TESOL Journal 2(1), 63-72.

Hammond, T., Clayton, B.M., \& Arnold, P.J. (2009). South Africa's transition from apartheid: The role of professional closure in the experiences of black chartered accountants. Accounting, organizations and society, 34(6), 705-721.

Hannon, B. (2014). Are there gender differences in the cognitive components of adult reading comprehension? Learning and Individual Differences, 32, 69-79.

Hartley, J., \& Trueman, M. (1986). The effects of the typographical layout of Cloze-tests on reading comprehension scores. Journal of Research in Reading, 9(2), 116-124.

Hirsch, E. D. (2003). Reading comprehension requires knowledge - of words and the world: Scientific insights into the fourth-grade slump and the nations stagnant reading comprehension scores. American Educator, 27, 10-13.

Human Science Research Council (HSRC) (2009). School Money: Funding the flaws, HSRC Review, 7(4) [Online] Available at: http://www.hsrc.ac.za/en/review/november2009/school-money (accessed 10 June 2015).

Hyde, J.S., \& Linn, M.C. (1988). Gender differences in verbal ability: A meta-analysis. Psychological Bulletin, 104, 53-69.

International Accounting Standards Board (IASB) $\left(2003^{\mathrm{a}}\right)$. Accounting Policies, Changes in Accounting Estimates and Errors, International Accounting Standard 8, London, UK: IASB.

International Accounting Standards Board (IASB) $\left(2003^{\mathrm{b}}\right)$. Inventories, International Accounting Standard 2, London, UK: IASB.

International Accounting Standards Board (IASB) $\left(2003^{\mathrm{c}}\right.$ ). Property, Plant and Equipment, International Accounting Standard 16, London, UK: IASB.

International Accounting Standards Board (IASB) $\left(2003^{\mathrm{d}}\right)$. Impairment of Assets, International Accounting Standard 36, London, UK: IASB.

International Accounting Standards Board (IASB) $\left(2003^{\mathrm{e}}\right)$. Investment Property, International Accounting Standard 40, London, UK: IASB.

International Accounting Standards Board (IASB) (2008). Business Combinations, International Financial Reporting Standard 3, London, UK: IASB.

International Accounting Standards Board (IASB) $\left(2010^{\mathrm{a}}\right)$. The Conceptual Framework for Financial Reporting 2010, London, UK: IASB.

International Accounting Standards Board (IASB) $\left(2010^{\mathrm{b}}\right)$. Framework-based teaching webcast. (Online) Available at:

http://media.ifrs.org/FrameWork101210/files/lobby.html. Accessed on 31 May 2015.

IFRS Rookies, (2015). IAS 16 Video 17 Eng Revaluation surpluses and deficits. Retrieved from: http://youtu.be/3uO0I-wcnqc

Janse van Rensburg, C., Coetzee, S.A., \& Schmulian, A. (2014). South African financial reporting students' reading comprehension of the IASB Conceptual Framework. Journal of Accounting Education, 32, 1-15. 
Jenkins, J.R., \& Jewell, M. (1993). Examining the validity of two measures for formative teaching: Reading aloud and maze. Exceptional children, 59(5), 421-432.

Jones, M.J. (1997). Critical appraisal of the Cloze procedure's use in the accounting domain. Accounting, Auditing \& Accountability Journal, 10, 105-128.

Jones, M. \& Smith, M. (2014). Traditional and alternative methods of measuring the understandability of accounting narratives. Accounting, Auditing \& Accountability Journal, 27(1), 183-208.

Keenan, J.M., Betjemann, R.S., \& Olson, R.K. (2008). Reading comprehension tests vary in the skills they assess: Differential dependence on decoding and oral comprehension. Scientific Studies of Reading, 12, 281-300.

Kendeou, P., \& van den Broek, P. (2007). The effects of prior knowledge and text structure on comprehension processes during reading of scientific texts. Memory \& Cognition, 35, 1567-1577.

Kim, J. Y., \& Anderson, T. (2011). Reading across the curriculum: A framework for improving the reading abilities and habits of college students. Journal of College Literacy \& Learning, 37, 29-40.

Klapwijk, N. M. (2013). Cloze tests and word reading tests: enabling teachers to measure learners' reading-related abilities. Per Linguam: a Journal of Language Learning, 29(1), 49-62.

Klare, G.R. (1988). The formative years. In B. Zakaluk \& S.J. Samuels (Eds.), Readability: Its past, present and future (pp. 14-33). Newark, DE: International Reading Association.

Koda, K. (2010). The role of reading in fostering transcultural competence. Reading in a Foreign Language, 22(1), 5-10.

Lei, S. A., Rhinehart, P. J., Howard, H. A., \& Cho, J. K. (2010). Strategies for Improving Reading Comprehension among College Students. Reading Improvement, 47(1), 30-42.

Lindsay, R.M. \& Ehrenberg, A.S.C. (1993), The Design of Replicated Studies, The American Statistician, 47(3), 217-228.

Logan, S., \& Johnston, R. (2010). Investigating gender differences in reading. Educational review, 62, 175-187.

Lynn, R., \& Mikk, J. (2009). National IQ's predict educational attainment in math, reading and science across 56 nations. Intelligence, 37, 305-310.

McKeown, M.G., Beck, I.L., \& Blake, R.G.K. (2009). Rethinking reading comprehension instruction: A comparisonof instruction for strategies and content approaches. Reading Research Quarterly, 44, 218-253.

McVee, M.B., Dunsmore, K., \& Gavelek, J.R. (2005). Schema Theory Revisited. Review of Educational Research, 75(4), 531-566.

Narvaez, D. (2002). Individual differences that influence reading comprehension. Comprehension instruction: Research based best practices, 158-175.

Nation, K., \& Snowling, M. (1997). Assessing reading difficulties: The validity and utility of current measures of reading skill. British Journal of Educational Psychology, 67, 359370.

National Academy of Sciences (NAS). (2012). Effective reading instruction. Retrieved from: http://www.nap.edu/openbook.php?record_id=13468\&page $=10$ 
Oakhill, J.V., \& Cain, K. (2012). The precursors of reading ability in young readers: Evidence from a four-year longitudinal study. Scientific Studies of Reading, 16, 91-121.

Pardo, L.S. (2004). What every teacher needs to know about comprehension. International Reading Association, 58(3), 272-280.

Pasquarella, A., Gottardo, A., \& Grant, A. (2012). Comparing factors related to reading comprehension in adolescents who speak English as a first (L1) or second (L2) language. Scientific Studies of Reading, 16(6), 475-503.

Patel, C., \& Day, R. (1996). The influence of cognitive style on the understandability of a professional accounting pronouncement by accounting students. The British Accounting Review, 28(2), 139-154.

Pearson, P.D., \& Hamm, D. (2005). The assessment of reading comprehension: A review of practices- past, present, and future. In S. G. Paris \& S.A. Stahl (Eds.), Children's reading comprehension and assessment (pp. 13-69). Mahwah, NJ: Erlbaum.

QS World University Rankings (2013). <http://www.topuniversities.com/universityrankings/world-university-rankings/2013\#sorting=rank+region $=+$ country $=+$ faculty $=$ + stars $=$ false + search $=$ pretoria $>$ Accessed 15.10.2014.

Raabe, A., Stevens, K.C., \& Stevens, W.P. (1984). Tax textbooks readability: an application of the Cloze method. Journal of the American Tax Association, 6(1), 66-73.

Rayner, K., Foorman, B., Perfetti, C., Pesetsky, D., \& Seidenberg, M. (2001). How Psychological Science Informs the Teaching of Reading. Psychological Science in the Public Interest, 2(2), 31-74.

Rankin, E.F., \& Culhane, J.W. (1969). Comparable Cloze and multiple-choice comprehension test scores. Journal of Reading, December, 193-198.

Reynolds, R.E., Taylor, M.A., Steffensen, M.S., Shirey, L.L., \& Anderson, R.C. (1982). Cultural schemata and reading comprehension. Reading Research Quarterly, 17(3), 353366.

Sartorius, K. \& Sartorius, B. (2013) The comparative performance of chartered accountancy students in South Africa: The impact of historical legacies. Development Southern Africa, 30(3), 401-416.

Schallert, D.L., \& Martin, D.B. (2003). A psychological analysis of what teachers and students do in the language arts classroom. Handbook of research on teaching the English language arts, (pp. 31-45). Mahwah, NJ: Erlbaum.

Shaffer, R.J., Stevens, K.T., \& Stevens, W.P. (1993). Assessing the readability of government accounting standards: The Cloze procedure. Journal of technical writing and communication, 23(3), 259-267.

Slavin, R.E. (1988). Educational Psychology: Theory into Practice. Englewood Cliffs, N.J.: Prentice Hall.

Spaull, N. (2013). Poverty \& privilege: Primary school inequality in South Africa. International Journal of Educational Development, 33(5), 436-447.

Stanat, P., Becker, M., Baumert, J., Lüdtke, O., \& Eckhardt, A.G. (2012). Improving second language skills of immigrant students: A field trial study evaluating the effects of a summer learning program. Learning and Instruction, 22(3), 159-170. 
Stead, B.A. (1977). Content Analysis and Readability Formulas as Applied To the Accounting Principles Board "Opinions". Journal of Business Communication, 14(3), 23-34.

Stevens, W.P., Stevens, K.C., \& Raabe, W. Jr. (1983). Communication in Accounting: Readability of FASB Statements. Review of Business and Economic Research, 19, 110118.

Stevens, K.C., Stevens, K.T., \& Stevens, W.P. (1993). A response to 'Measuring readability: a comparison of Accounting textbooks'. Journal of Accounting Education, 11, 287-292.

Stone, G., \& L. D. Parker. (2013). Developing the Flesch reading ease formula for the contemporary accounting communication landscape. Qualitative Research in Accounting and Management, 10(1), 31-59.

Tabatabaei, O., \& Mirzaei, E. (2014). Correlational Validation of Cloze Test and C-Test against IELT. Journal of Educational and Social Research, 4(1), 345-356.

Taylor, W.L. (1953). Cloze procedure: A new tool for measuring readability. Journalism Quarterly, 30, 413-433.

Taylor, W.L. (1956). Recent developments in the use of the Cloze procedure. Journalism Quarterly, 33, 42-48, 99.

Taylor, W. (1957). 'Cloze' readability scores as indices of individual differences in comprehension and aptitude. Journal of Applied Psychology, 41(1), 19-26.

Tomlinson, C.A. (August, 2000). Differentiation of Instruction in the Elementary Grades. ERIC Digest. ERIC Clearinghouse on Elementary and Early Childhood Education.

Wells, M.J.C. (2011). Framework-based Approach to Teaching Principle-based Accounting Standards. Accounting Education: an International Journal, 20(4) 303-316.

Widmayer, S.A. (2005). Schema Theory: An Introduction. Educational Psychology, Retrieved from http://www.saber2.net/Archivos/Schema-Theory-Intro.pdf.

Williams, R.S., Ari, O., \& Santamaria, C.N. (2011). Measuring college students' reading comprehension ability using Cloze tests. Journal of Research in Reading, 34(2), 215231.

Williamson, G.L. (2008). A text readability continuum for postsecondary readiness. Journal of Advanced Academics, 19(4), 602-632.

Zoghi, M., Mustapha, R., Rizan, N., \& Maasum, M. (2010). Looking into EFL reading comprehension. Procedia - Social and Behavioral Sciences, 7, 439-445. 